\title{
A Tale of two "Smart Cities": Investigating the Echoes of New Public Management and Governance Discourses in Smart City Projects in Brazil
}

\author{
Erico Przeybilovicz \\ EAESP FGV \\ erico.prz@fgv.br
}

\author{
Maria Alexandra Cunha \\ EAESP FGV \\ alexandra.cunha@fgv.br
}

\author{
Javiera Fernanda M. Macaya \\ EAESP FGV \\ javiera.macaya@gmail.com
}

\author{
João Porto de Albuquerque \\ University of Warwick \\ j.porto@warwick.ac.uk
}

\begin{abstract}
This study investigates the influence of discourses of New Public Management and e-Governance on the manner in which Information Technology (IT) has been conceived in recent smart city initiatives in Brazil. A critical discourse analysis is conducted as the methodological approach to investigate the role of IT in smart city discourses of two cities. The main result has shown that the role of technology within the two cases strongly reflects the discourses of New Public Management and e-governance, in which there is clearly a latent tension between top-down and bottomup approaches to smart cities.
\end{abstract}

\section{Introduction}

Making “a city smarter” is an objective of new urban agendas in a context of increasing urbanisation, and a phenomenon that has revived old problems and raised new challenges for cities [17]. The concept of smart cities has emerged from recent developments in digital technologies and their incorporation in the so-called "smart urbanism" [27] within the field of city planning. Previous analyses in this field (e.g. [18] and [36]) have criticised the top-down and technology-driven approach adopted by many smart city projects. These authors argue that there is a need to emphasise the role of grassroots movements such as civic hackers [36] and an increase in stakeholder participation as a means of effectively fostering local innovation [18]. Although it is apparent that the tension between "top-down" and "bottom-up" approaches underlies many smart city initiatives around the world, there is currently little understanding of how this tension materialises in concrete scenarios and discourses and what its implications are in terms of governance.

In recent investigative studies in Brazil, we (the authors of this study) have observed public and technology managers describing their smart city projects on the basis of arguments similar to those used in major e-government and e-governance projects of the 1990s. This realisation has prompted us to ask the following research questions: Have New Public
Management (NPM) and e-Governance discourses had any discernible influence on the manner in which information technology (IT) has been conceived in recent smart city initiatives? How is the role of IT related to the tension between "top-down" and "bottom-up" approaches to smart cities? This paper investigates these two questions through a critical discourse analysis of the projected role for IT within smart city initiatives in two Brazilian cities. The results of our analysis show that smart city initiatives in Brazil are reproducing the discursive space that was defined almost two decades ago with the emergence of egovernment projects. The roles projected for IT within current smart city discourses reflect an opposition inherited from the discourses around e-government and e-governance, i.e. they are associated with a latent tension between an emphasis on employing IT to pursue gains in managerial efficiency versus the attempts to expand citizen participation and collaboration by means of information and communications technologies (ICTs). The main contribution of this work is to provide evidence that the tension between "top down" and "bottom up" smart city approaches are echoing discourses on e-government and e-governance, which are in turn related to the opposition between public administration discourses around New Public Management and governance. This is a first step towards gaining a deeper understanding of whether (and how) the influence of these discourses materialises in areas related to technology such as infrastructure, data policy and openness, technology contracting procedures and the interaction with the software development business sector.

The remainder of this paper is organized as follows. Section 2 presents background research on smart cities. Section 3 presents details of our analytical framework by contrasting New public management/e-Government vis-à-vis Governance/e-Governance. Section 4 presents the methodology adopted, whilst Section 5 presents and discusses our results. Section 6 proposes final considerations. 


\section{Smart cities}

The term "smart city" can be related to planning policies and ideals and particularly to the concept of smart growth that emerged within the context of New Urbanism in the 1980s [15] [19]. New Urbanism sought to improve the urban environment and quality of life in cities by giving voice to communitarian ideas and limiting urban sprawl and land occupation, as well as opposing forms of development driven by the logic of the automobile and individual mobility. One objective of New Urbanism is smart growth, a planning strategy aimed at making cities more compact [4], widening possibilities for more effective public transport solutions, better waste handling solutions, less environmental pollution, etc. The adjective "smart" is generally associated with the relationship between urban space and the technological layer and includes issues such as the ability to bring about innovation; the transition to forms of e-governance and social learning; and the prospect of providing an information and communications technology (ICT) infrastructure [6] [24] [19]. It is reasonable to assume that the concept of a smart city derives from the overlapping assemblage of the two following theoretical factors: New Urbanism and the wave of ICT development [19][28][2]. The different and often complementary perspectives of a smart city encompass the efficient, technologicallyadvanced, sustainable and socially inclusive city [37].

The term "smart city" is positioned as the latest phase of urban development, in the wake of narratives about the sustainable city and the 'informational' city [37]. The creation of the smart city concept is culturally and politically linked to the tension between different forces, such as the following: i) the institutional reorganisation of territorial structures; ii) the powers of the government and regulatory mechanisms aimed at reducing environmental impact; iii) demands for environmental justice by social movements, associations and other socially-based forces, in addition to the environmental awareness of citizens and consumers; and iv) the appropriation of the environmental discourse by companies and economic agents eager to employ the rhetoric of sustainability to reformulate or justify their activities [37].

A smart city can be conceived as an objective for urban development schemes such as 'a good place to live in', 'a healthy city' and 'technologically advanced' [37]. The term smart city can also be employed for urban management and the political and economic urban elite classes, to support particular policies involving urban development. There are several links between neoliberal urban policies for development and the concept of the smart city: the creation of the image of a clean green and intelligently-planned city is able to attract investment, qualified professionals and tourists [5] [20] [19].

Smart city initiatives and networks led by the hightech industry seem to be more focused on advancing the use of technology, particularly when it involves the analysis of "big data" [36]. This narrative focuses on the competitiveness of cities and their ability to respond to environmental challenges through ICT and networkbased urban solutions [39]. Business promoters propose that a smart city should use an efficient ICT system to monitor and control the city in real-time [18]. The technologies can enable aspects of the city to be managed more efficiently and effectively on the basis of more dynamic evidence [22], although this has been criticised as a "corporatisation of city governance" [22]. In this view, smart city initiatives are centred on a kind of technocratic governance that is very narrow in scope and reductionist and functionalist in approach. These initiatives are often based on a limited set of particular types of data and fail to take account of the broader effects of culture, politics, policymaking, governance and capital that shape city life and the way it unfolds [22].

Another branch of the literature on smart cities is focused on their governance [29]. Smart city initiatives can be based on narratives of open ecosystems for innovation, with social participation at organisational, individual and cultural levels [16], i.e., they require local innovation and the involvement of interested parties to successfully pursue "smart" objectives [18]. These factors, which extend beyond strictly technological factors, are addressed by authors such as Townsend [36], Nam and Pardo [30][31] and Chourabi et al. [7]. They argue that data and technologies must be complemented with a wide range of other instruments, policies and practices, which must be sensitive to the diverse ways in which cities are structured and function [22]. These critical discourses embrace a "bottom-up" perspective that emphasizes the use of IT for civic engagement, such as in civic hacking and e-participation mechanisms. They contest and oppose the "top-down" perspective of a city governed by data-driven and centralising technologies. Thus, this tension between "top-down" and "bottom-up" approaches underlies the role projected for IT in smart cities worldwide.

\section{Opposing and similar discourses: NPM and e-Government versus Governance and e-Governance}

The concept of NPM emerged between the 1980s and 1990s as a means of tackling public administration problems by employing management tools from the private sector [33] intended to reduce the size of the 
State. The tenets of NPM recognised the value of increased efficiency, and laid emphasis on competition and the accountability of political actors. Since it was underpinned by a neoliberal ideology, it wanted to have a managerial perspective of public administration, with a more independent and autonomous administration that sought to achieve greater efficiency [33]. In this climate, the role of elected politicians is reduced to managerial aspects and the citizen is viewed as a customer - or consumer - of public services [21][8][9]. The concept of e-government arose in the wake of state reform, and was, to a great extent, inspired by the precepts of NPM. As a result, factors such as performance, efficiency, effectiveness, transparency, control mechanisms, the quality of public spending and accountability were all related to the process of modernising public administration and had a strong influence on the planning of e-government programmes. The inclusion of these issues in public policies and clearly-defined initiatives in government programs, required the use of technology, to ensure that these features of egovernment programmes could leverage new levels of efficiency in public administration [13]. In some cases, the use of the term 'e-government' was linked to the modernisation of public administration through the use of ICT and improvements in the efficiency of operational and administrative government processes. In other cases, it was clearly combined with the public sector's use of the Internet to provide electronic public services.

The concept of governance can be understood as a new role of the State which, subject to operational constraints, has the ability to stimulate, coordinate and facilitate relationships with the private sector and civil society [33]. Although governance arose from within the conditions created by NPM, the following points differentiate the concepts and place them in an analytical opposition [33]: (i) Although the State has reduced powers, its role is not diminished but rather transformed, and its involvement is essential for coordinating networks between public and private organisations; (ii) these networks are interorganisational; (iii) governance does not rely on a fixed operational model but is flexible and can be applied to different circumstances. Moreover, governance approaches aim at taking account of the context in question unlike NPM, which does not take into account the specific features of the reality in which it is implemented.

Although they have a similar operational base, NPM and governance discourses differ significantly when analysed at a theoretical level [33]. In short, NPM is a closed programme that is strongly driven by marketoriented ideologies and does not include the context or culture of the place where it will be implemented. In contrast, governance concerns a political theory which seeks to understand the procedures in which it is involved and to attempt to involve other key players, as well as to take full account of its context [34]. These authors make clear that "governance is a blending of private and public values and NPM can be described as a unilateral infusion of corporate-sector values and objectives into the public sectors and public-service production and delivery (...)" [34]. Therefore, governance seeks to be a central feature in democratic politics with the aim of balancing and improving the responsibilities and features of the State, in addition to those of other actors from society and the private sector. Although public resources are still under the control of elected politicians, in view of the possible interchange between the State and society, the role of governance is to plan strategies that can strengthen the State's ability to act. By implementing ICT, governance is able to create a new paradigm: e-governance, which includes the prospect of using the Internet to make the State's activities more effective, provide easy access to public services and encourage citizen participation in democratic practices.

Lawson [25] argues that a more powerful vision of e-governance would run parallel with changes in the operation and functioning of the State, by transforming the culture and whole structure of government, as well as adopting a new approach. Thus, according to this author, as well as rendering services to citizens in a more effective way, the use of ICTs could also form the basis for the creation of networks and forms of participation. The use of ICT by the government can increase citizen participation in decision-making processes, and encourage innovation in the relationship between governments and citizens [38]. As Kolsaker and LeeKelley [23] argue, for e-governance to be successful, it is important for citizens to be prepared to understand and express their opinions, just as the State must be prepared to provide information and create spaces for discussion and debates with citizens. In summary, the use of technology could be aligned with more managerial practices of e-government that echo NPM discourses; or participatory e-governance initiatives that resonate governance discourses.

A parallel can be established between the opposed roles played by IT in e-government and e-governance initiatives (which echo discourses of NPM and governance), and the tension between top-down versus bottom-up approaches in smart cities. Although this parallel is conceivable, to our knowledge, this is the first work to propose this relationship and investigate empirically whether (and how) it is incorporated into the discourse of public managers who are in charge of smart city initiatives. 


\section{Methodology}

This study investigates the proposed association between NPM/governance discourses and the role of IT in smart cities initiatives. The method employed is a double case study comprising two smart city initiatives in Brazil. It is conducted from the perspective of municipal administrators, whose statements are examined by means of a critical discourse analysis (CDA). CDA has been described as a suitable approach for producing useful and significant insights into the manner in which a discourse reproduces (or resists) political and social inequality, abuse of power and domination [1]. CDA "interrogates" texts to reveal the inner patterns, systematic communicative distortions and power relations underlying discourse [10]. The method used was that set out by Thompson [36], which had previously been employed in IT studies [12]. CDA relates micro-level texts (the level of the text) to the macro power structures (sociocultural practices) that these texts reproduce. In CDA, the discursive practice is the mediator between the macro and the micro levels (Figure 1).

The interpretive phase in the practical application recommended by Thompson [35] can be carried out though a wide range of concepts and strategies such as analytical concepts, positioning, narrative, metaphor and restructuring. In our analysis, we have decided to investigate the proposition that the discourse of smart cities initiatives reproduces the discursive space that was defined, following the emergence of e-government in the 1990s, when there was a sharp antagonism between two ideas, that was largely defined by undisclosed concepts. NPM and e-governance concepts are not necessarily disjoint in practice and practical initiatives may be influenced by both simultaneously. However, we use them here in analytical opposition in CDA, as ideal types with the function of revealing the emphases and focuses identified in the discourses. The discourses are not independent but are formed on the basis of a complementary or competitive relationship between themselves [3]. The relationship can be understood from the "concept of discursive formation" to shape groups of utterances and relate them to the same system of historically-determined rules. Since it could be exaggerated to designate e-government as a discursive field, we are going to call it a discursive space. In each discursive space, there are at least two discursive formations which have special positions [3].

A discursive formation is opposed to two sets of semantic categories, the asserted (which we call 'positive') and the refused (the 'negative') [26]. The discourses construct their identities reciprocally, together with the other discourses, which in turn, allow these relations to be established. This can be stated because the relations of intertextuality are constitutive or, in other words, attribute meaning to the discourses. Hence, if, at least seemingly, a discourse is found to be indifferent to another, from a semantic standpoint, it is important for this discourse to be denied in the same field while at the same time, in some way it "is prevented" from evolving outside of this field [3].

In discourses in which there is an emphasis on managerialism, performance, efficiency, effectiveness, transparency, control mechanisms, the quality of public spending and accountability, this was associated with the legacy of NPM. In contrast, wherever there has been an emphasis on expanding citizen participation and collaboration, this was understood as a new form of governance made possible by ICT and associated with governance discourses. NPM discourses are not necessarily antagonistic to widened participation and co-construction but they pay little attention to these issues. Governance discourses do not deny the importance of performance and efficiency but they place very little emphasis on them.

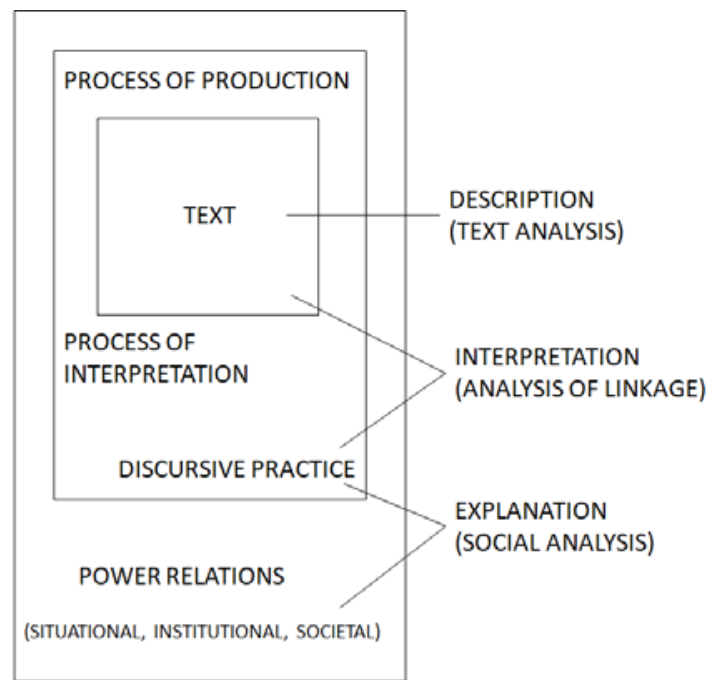

Figure 1. Dimensions of discourse and discourse analysis (adapted from Thompson [35])

\subsection{Data collection and analysis}

This study is based on interviews conducted in 2015 in two Brazilian cities carrying out smart city initiatives as a part of a larger project that investigates about the concept of smart cities in the view of public managers [11]. We acknowledge that in critical research, providing situational context information is important to substantiate the plausibility of the results. However, in this research, we were not able to identify the names of the cities analysed as a consequence of our ethical commitment to the interviewees, who expressed concerns of being identified. They can be both generally 
characterized as large cities in south-eastern Brazil, which is the region with the highest gross domestic product (GDP) and population density in the country. These cities are chosen as representatives of cities implementing projects under the label of "smart cities", independent from their inclusion or not in the controversial rankings and lists of "smart cities". Although two cities make a small sample for a drawing general conclusions, our purposive sample of two contrasting cases may offer important insights into differences and commonalities for an in-depth analysis and generation of hypothesis for further research. The mayors of these two cities belong to two different and opponent parties in Brazil's complex multi-party system. In the first city, interviews were conducted with the following five people: the mayor, the secretary of administration and three technology managers. In the second city, interviews were conducted with two government secretaries, two public managers involved in the area of smart cities and the president of a State IT company. The interviews were recorded and transcribed, (with one exception due to a technical problem over recording and its analysis, whose analysis was based on two researchers' notes).

The data were processed in accordance with asserted ("positive”) semantic categories; for example, in NPM, these included efficiency, effectiveness, control and a better use of resources. Additionally, rejected or absent ("negative”) categories were used such as e-governance and managerialism. We also identified the concerns that most affect urban management, such as the need for more compact cities. Using Fairclough's [14] method, we processed the data in the three stages of description, interpretation and explanation: 1) The texts were read so that they could be described; 2) in interpretation, we sought to identify the categories either accepted by discursive formations ("positive”) or rejected by them ("negative”). We identified 217 extracts from texts and linked them to other extracts on the basis of similarity. The categories were drawn on and combined in the interpretation and explanatory stages; 3 ) as we read (and reread) the transcripts, we created a framework to define the concepts that corresponded to those in the explanatory stage. Official documents and websites were used as a basis to describe the cities and their context.

\subsection{Introducing the two cities}

City 1 is considered a medium-sized city according to Brazilian standards and has a GDP of more than US\$ 11 billion (2012), which is among the 20 highest in Brazil in 2012. In 2015, the municipal budget was close to US\$ 800 million. In terms of the Human Development Index (HDI 0.840), it is among the top 10 cities in Brazil. It is a compact city which has already solved some typical challenges of Brazilian cities, such the provision of water and sanitation services. However, despite these high economic and human indicators, the city has vulnerable and impoverished areas, although it is an economically developed city without a budget deficit. This availability of financial resources allowed an operations centre to be established; the city has more than 130 video cameras for monitoring and a situation room in which it is possible to monitor, for example, all entries into the city. Recently, the city was provided with funds from a development bank to automate public administration processes. An official report states that the objective of the scheme is to make "public administration more flexible by reducing the processing time for administrative tasks. It will also create savings by avoiding the use of paper, printing, transport and storage and making it possible to retrieve and monitor productivity indicators". Furthermore, "now that the democratic regime has been consolidated, the search for efficiency has become the greatest challenge for public administration". The city is currently managed by a traditional political party regarded as being conservative ("centre-right"), with predominant orientation towards more centralized decision-making processes.

As for City 2, in 2012 its GDP was more than US\$ 100 billion, and it is also among the top 20 cities in Brazil in 2012, and had a municipal budget of more than US\$ 10 billion in 2015. An HDI of 0.805 places it among the top 30 cities in the national human development ranking. However, the city has great social inequalities; with sharp contrasts between the rich, and extremely poor districts. City 2 is spread out and has the typical features of cities in developing countries irregular land use, a lack of infrastructural facilities, a lack of housing and the presence of shanty towns, a marginalization of the poor community, social inequality, pollution and an urban sprawl that has expanded over several decades. None of the interviews noted problems related to a lack of resources. The managers appeared to be concerned with mobility issues, such as laying out cycle tracks, expanding public transport, reducing the use of individual automobiles, and reducing the speed of vehicles in the main avenues. The current management is also concerned with having a government that encourages greater citizen participation; there is an initiative to incorporate management principles in open government. They draw attention to the challenge of tackling chronic housing and basic sanitation problems, together with a range of current problems, such as mass Internet access and social diversity. The two issues are of equal importance. On the city's website, there is information about smart street lighting projects, apps for citizen services and the availability of Wi-Fi in the city, among other projects. 
The website contains the important phrase "the city we want is transparent, participatory, fair and innovative". The city is currently managed by a traditional party regarded as moderate liberal ("centre-left").

\section{Results and discussion of smart city discourses}

In our analysis, we sought to identify the categories asserted by ("positive") and rejected by ("negative") discursive formations. Table 1 illustrates the interpretation stage of our analysis and gives examples of interview quotations that are categorized according to assertions or rejections in relation to NPM or eGovernance. The columns with numbers indicate the number of quotations that are associated to a given perspective. Although the analysis is not quantitative, the number of quotations helps to show the emphasis given by the discourses.

In City 1, we predominantly identified echoes of NPM. Technology is regarded as a means of solving administrative problems and even as a way of curbing environmental and social problems and handling crisis situations. The smart city projects that are being implemented there are carried out in partnership with large international companies of IT consultancy services. The managers of City 1 attach importance to managerialism, performance, efficiency, control mechanisms, the quality of public spending and accountability: "We implemented digital processes, since they are faster and more agile" (1A). They speak of their commitment to signing management contracts with specific goals and defined indicators for most departments and "producing a culture oriented towards goal and results in public management” (1A) as a means of improving it and providing quality services for citizens. They lay emphasis on monitoring and control by establishing an operations centre and installing surveillance cameras in the city for public safety, which is a serious concern of Brazilians. "We have invested heavily in surveillance camera technology" (1A).

In City 2, the echoes of e-Governance were most prominent. Although the implementation of IT projects and smart city initiatives is not completely performed in a bottom-up fashion, there is a view of the city as an open ecosystem that cannot be fully controlled. This has a significant impact over the governance mechanisms adopted: they include initiatives for enlarged governance, such as the use of open government and open data, increased citizen participation and the development of collaborative solutions.

The managers of City 2 stress the importance of increased participation and collaboration, which is a new form of governance made possible by ICT. They reaffirm the commitment of management to expanding citizen participation in a collaborative effort to tackle the city's problems, such as "the presence of businesses and services throughout the city, not only in the expanded centre" (2D) and being a city that includes and embraces social diversity. ICT is viewed as enabling participation, collaboration and innovation for an "intelligent urbanism", which is the result of a democratic construction" (2D). The city should be concerned with the people who live there, and they are the individuals who can help build a better city to live in, "by bringing together the different cities within a single city" (2B); the city cannot be controlled from an operational centre, given the fact that "there are different dynamics and there is no one centre that can coordinate it all” (2B).

However, CDA also involves identifying the discursive formations absent from the informants' statements. In City 1, elements of governance, citizen participation, collaboration, co-creation, a bottom-up approach, innovation and the city as a dynamic ecosystem are all absent. In contrast, in city 2, elements of the NPM discourse appear in the informants' statements but mostly in a negative manner. The informants recognise that technology can be used to control, monitor and manage the city but believe that this strategy is not the solution for smart cities.

Issues related to new urbanism are present in both cities. An "urban space has to be imagined as a place of common living, where people can interact, socialise and move freely, walking, cycling or using efficient public transport” (1A) as well as a "balanced city” (1B) and a “compact and dense city” (2D).

In the explanation stage, we sought to provide a comprehensive analysis of the social context in connection with our previous theoretical framework on NPM and Governance discourses (Section 2). Furthermore, we linked our interpretation of the empirical material with the wider social and political context in Brazil. In this context, the e-government movement at the beginning of the 2000s was influenced by the large suppliers of technology and by the ideals of multilateral agencies [13]. Since this period, there has always been a general dissatisfaction with local government management and the NPM has gathered strong arguments with regard to the perception in Brazil of governments not being very efficient or effective.

Finally, we sought to theorize about the empirical findings to identify characteristics in the discourses about the use of information technology in smart cities that can be associated to the discourses of NPM and Governance. Table 2 summarizes the results of the explanation stage, in which we determined characteristics of the discursive spaces of the role of technology in smart cities projects that echo the 
discourses of NPM and Governance. In general, NPM is echoed in characteristics of the smart city discourse that emphasise a focus on centralization and public management efficiency, control and monitoring. In contrast, e-Governance is echoed in characteristics that lay the focus on collaboration, are based on the view of a city as a dynamic ecosystem, and contain a more or less explicit critique to technocratic and corporatized city governance styles.

The characteristics identified in Table 2 and their underlying tensions permeate several of the success factors reported in the smart cities literature [31][7][32], such as organization (e.g. "integration and coordination of processes”), policy (“public policy effectiveness”), people/communities ("fostering citizen participation”). In this manner, the characteristics we identified have not been properly taken into account in the existing literature and can be considered to orthogonal to the aspects that are emphasized in the Information Systems community.

The opposing characteristics of NPM and eGovernance are contrasted in Table 2 to make evident that, although not mutually exclusive, they express tensions in terms of emphasis given to certain goals (e.g. improving quality of existing services versus reducing unserved demands), ideals (e.g. efficient city versus humanized city), inter-organisational associations (e.g. public-private partnership versus partnerships with social actors) and the relationship with citizens (e.g. service provision versus citizen participation). We thus propose that the legacy of NPM and e-Governance discourses is associated with characteristics of the smart city discourse (enumerated in Table 2), which in turn reflect the tension between top-down and bottom-up approaches recognised in critical discourses about smart cities (e.g. Townsend [36], Goodsped [18]. In this manner, the identification of characteristics of smart city discourses that incorporate the tension between topdown and bottom-up approaches is an important contribution to understand more concretely how this tension is shaping smart cities initiatives and positioning them in relation to public management debates around NPM and e-Governance.

Table 1. A summary of the CDA analysis (interpretation stage): positive and negative aspects of smart cities discourses

\begin{tabular}{|c|c|c|c|c|c|c|}
\hline Interv & Description & Persp. & “Positive" & $\begin{array}{l}\text { N. } \\
\text { Q. }\end{array}$ & "Negative" & $\begin{array}{l}\text { N. } \\
\text { Q. }\end{array}$ \\
\hline \multirow[t]{2}{*}{$1 \mathrm{~A}$} & \multirow[t]{2}{*}{$\begin{array}{l}\text { Public executive } \\
\text { and an advisor } \\
\text { describes smart } \\
\text { city projects } \\
\text { (interview) }\end{array}$} & NPM & $\begin{array}{l}\text { "...monitoring the city. CCTV, } \\
\text { cameras, we have heavily invested } \\
\text { in this technology." } \\
\text { "Bonus for servers, it produces a } \\
\text { culture of 11goals and results in } \\
\text { public management." }\end{array}$ & 31 & Not found & 0 \\
\hline & & e-gov & $\begin{array}{l}\text { "a feeling that you belong to your } \\
\text { city" }\end{array}$ & 1 & Not found & 0 \\
\hline \multirow[t]{2}{*}{ 1B } & \multirow[t]{2}{*}{$\begin{array}{l}\text { Public executive } \\
\text { and } \quad 3 \text { IT } \\
\text { professionals } \\
\text { describe their } \\
\text { Smart City } \\
\text { vision and } \\
\text { projects under } \\
\text { development }\end{array}$} & NPM & $\begin{array}{l}\text { "we could check now what time you } \\
\text { arrived in the city (...) and the time } \\
\text { you left it, if only your car license } \\
\text { was given to me" } \\
\text { "we start to have deadlines and } \\
\text { control over the city in an intelligent } \\
\text { way. " }\end{array}$ & 31 & Not found & 0 \\
\hline & & e-gov & Not found & 0 & Not found & 0 \\
\hline \multirow{2}{*}{$2 \mathrm{~A}$} & \multirow[t]{2}{*}{$\begin{array}{l}\text { Concept of } \\
\text { smart city. Two } \\
\text { different } \\
\text { interviews }\end{array}$} & NPM & $\begin{array}{l}\text { "all this innovation is generating } \\
\text { productivity gains" }\end{array}$ & 4 & $\begin{array}{l}\text { "Smart City has a bias towards } \\
\text { big control rooms, large-scale } \\
\text { automation, what I don't think } \\
\text { is really that smart" }\end{array}$ & 2 \\
\hline & & e-gov & $\begin{array}{l}\text { "the cities will become really smart } \\
\text { when you manage to touch this } \\
\text { public sector governance” }\end{array}$ & 5 & Not found & 0 \\
\hline
\end{tabular}




\begin{tabular}{|c|c|c|c|c|c|c|}
\hline \multirow[b]{2}{*}{$2 B$} & \multirow[b]{2}{*}{$\begin{array}{l}\text { IT manager with } \\
\text { his assistant. } \\
\text { Views about } \\
\text { technology and } \\
\text { smart city. }\end{array}$} & NPM & $\begin{array}{l}\text { "the city managed in a technological } \\
\text { way" }\end{array}$ & 8 & $\begin{array}{l}\text { "I don't see by } 2030 \text { a city } \\
\text { completely managed by devices } \\
\text { systems etc." }\end{array}$ & 10 \\
\hline & & e-gov & $\begin{array}{l}\text { "mobile apps that stimulate } \\
\text { citizenship, participation, collective } \\
\text { discussion of problems" } \\
\text { "information transparency, open } \\
\text { (data), APIs made available for the } \\
\text { development of apps that dialogue } \\
\text { with the city, the public } \\
\text { administration etc." }\end{array}$ & 26 & Not found & 0 \\
\hline \multirow[b]{2}{*}{$2 \mathrm{C}$} & \multirow{2}{*}{$\begin{array}{l}\text { Public manager } \\
\text { and a team } \\
\text { member } \\
\text { describe their } \\
\text { smart city } \\
\text { concept and the } \\
\text { ongoing projects } \\
\text { and priorities. }\end{array}$} & NPM & $\begin{array}{l}\text { "to establish quantitative indicators } \\
\text { of our capacity to achieve targets } \\
\text { and qualitative of the way we } \\
\text { achieve it, if there's an effect or not" }\end{array}$ & 12 & $\begin{array}{l}\text { "Today's Market does not offer } \\
\text { solutions that dialogue with } \\
\text { what we are wanting to do" } \\
\text { "There isn't an ideal city } \\
\text { model" }\end{array}$ & 13 \\
\hline & & e-gov & $\begin{array}{l}\text { "a smart city is a city which consults } \\
\text { more, distributes more, has more } \\
\text { participation, since participation is } \\
\text { fundamental for the citizenship. So, } \\
\text { a smart city is a citizenry city." }\end{array}$ & 49 & $\begin{array}{l}\text { "The market is focusing on } \\
\text { making money, the public } \\
\text { administration wants to recover } \\
\text { from its longstanding problems } \\
\text { and the society is completely } \\
\text { apart from this." } \\
\text { "It is pointless to make } \\
\text { something very open if we can't } \\
\text { give the proper importance and } \\
\text { catalyse the debate around this." }\end{array}$ & 8 \\
\hline \multirow[b]{2}{*}{$2 \mathrm{D}$} & \multirow[b]{2}{*}{$\begin{array}{l}\text { Public manager } \\
\text { with } \\
\text { communications } \\
\text { director } \\
\text { describing } \\
\text { perceptions } \\
\text { about smart city } \\
\text { from an } \\
\text { urbanistic } \\
\text { perspective. }\end{array}$} & NPM & $\begin{array}{l}\text { "The use of innovation based on } \\
\text { technological processes to provide } \\
\text { more efficiency for the service } \\
\text { provision." }\end{array}$ & 1 & $\begin{array}{l}\text { "There isn't an ideal model, } \\
\text { each city has its geography and } \\
\text { socio-political situation”. }\end{array}$ & 2 \\
\hline & & e-gov & $\begin{array}{l}\text { "Connected city, using the } \\
\text { information to empower the } \\
\text { population to accompany demands } \\
\text { and decisions of the public } \\
\text { administration and public policy } \\
\text { making" } \\
\text { "Replacing a model of citizen } \\
\text { alienation through technology by a } \\
\text { model in which people use } \\
\text { technology to build society. } \\
\text { Reversal of the roles between } \\
\text { society and technology." }\end{array}$ & 7 & Not found & 0 \\
\hline
\end{tabular}

Note: N.Q. - number of quotations.

Table 2. Echoes of New Public Management and e-Governance in the smart city discourse.

\begin{tabular}{|l|l|}
\hline \multicolumn{1}{|c|}{ New Public Management Echoes } & \multicolumn{1}{c|}{ e-Governance Echoes } \\
\hline $\begin{array}{l}\text { Improving the quality of public services - readiness, } \\
\text { speed and quality of service }\end{array}$ & $\begin{array}{l}\text { Technology support to public policy towards reducing } \\
\text { unserved demands - towards a more equitable, less } \\
\text { unequal and more just city }\end{array}$ \\
\hline $\begin{array}{l}\text { Efficient city - improved public management } \\
\text { processes in efficiency, transparency, digitization, } \\
\text { control, improved quality in the public expenditure, } \\
\text { economic performance, productivity }\end{array}$ & $\begin{array}{l}\text { Humanized city - improved quality of life, widening } \\
\text { participation and citizen rights, encouraging and } \\
\text { supporting diversity }\end{array}$ \\
\hline Public policy effectiveness & $\begin{array}{l}\text { Decentralization - in public management and decision- } \\
\text { making }\end{array}$ \\
\hline
\end{tabular}




\begin{tabular}{|l|l|}
\hline People as assets & Increasing the links between the citizen and the city \\
\hline Service provision to citizens & $\begin{array}{l}\text { Fostering citizen participation - interaction, collective and } \\
\text { individual participation and decision-making, public } \\
\text { monitoring, empowerment }\end{array}$ \\
\hline $\begin{array}{l}\text { Public-private partnerships, focus on the with the } \\
\text { business sector, financing and resource management }\end{array}$ & Partnership with social actors \\
\hline $\begin{array}{l}\text { City control - involving public management and } \\
\text { beyond: street lights, traffic control, public transport, } \\
\text { garbage collection services, public schools, } \\
\text { surveillance }\end{array}$ & $\begin{array}{l}\text { Simplicity - solutions that could be understood by } \\
\text { everyone }\end{array}$ \\
\hline $\begin{array}{l}\text { Integration and coordination of processes, data, } \\
\text { actions and policymaking }\end{array}$ & Participatory development of technology \\
\hline Single and shared view of the city & Information for all - transparency as a basis for dialogue \\
\hline
\end{tabular}

\section{Final considerations}

The analysis performed in this paper provides solid evidence that echoes of the discourses around NPM and governance underlie the smart city discourses of the two cities analysed. This is clearly connected to the latent tension between top-down and bottom-up approaches to smart cities. Furthermore, in both cities studied these discourses connected typical elements of the "new urbanism" themes such as quality of life, the compact city and the consumption of fewer resources. Therefore, this paper adds to the existing literature on smart cities by identifying a set of characteristics of smart city discourses that reverberate NPM and governance discourses. This association enables us to propose that the tension between centralization/topdown versus participation/bottom-up as a constitutive tension underlying the role of IT in smart city projects. This tension and our identified characteristics have not been investigated in-depth by the IS research community so far, so that future work is needed for understanding to what extent they are shaping smart city initiatives worldwide, particularly in relationship with the IR infrastructure and the implementation of urban services.

Further investigation should be conducted on how the identified discourse characteristics are materialised in the elements and governance mechanisms of the smart city. More specifically, additional investigation could establish how the top-down/bottom-up tension is reflected in the particular technologies and artefacts that are deployed such as the city's IT infrastructure, its open data policy, and the interaction mechanisms with the business sector and other social actors.

\section{Acknowledgments}

We extend our thanks to Prof. Mario Aquino Alves for helpful advice on CDA, Telefónica|Vivo and to São Paulo Research Foundation (FAPESP) for funding the research project, grant\#2015/22960-1., grant\#2015/50133-2.

\section{References}

[1] S. Ainsworth, C. Hardy, and Harley, B. Online Consultation: e-democracy and e-resistance in the case of the development gateway. Management Communication Quarterly, 2005, 10, pp. 120-145.

[2] S. Allwinkle, and P. Cruickshank. Creating smart-er cities: an overview, Journal of Urban Technology, 2011, 18(2), pp. 1-16.

[3] M. A. Alves. Análise crítica do discurso: exploração da temática, 2006, São Paulo: FGV.

[4] T. Beatley, and R. Collins. Smart growth and beyond: transitioning to a sustainable society, Virginia Environmental Law Journal, 2000, 19(3), pp. 287-322.

[5] P. Brand. Green subjection: the politics of neoliberal urban environmental management, International Journal of Urban and Regional Research, 2007, 31(3), pp. 616-632.

[6] M. Castells, and P. Hall. Technopoles of the World, 1994, London: Routledge.

[7] H. Chourabi, T. Nam, S. Walker, L. R. Gil-Garcia, S. Mellouli, K. Nahon, J. R. Scholl. Understanding smart cities: An integrative framework. Paper presented at the 45th Hawaii International Conference on System Sciences, 2012, Maui, HI, pp. 2289-2297.

[8] T. Christensen, P. Lægreid. A transformative perspective on administrative reforms. In: Christensen, T. Lægreid, P. New public management. The transformation of ideas and practice. Aldershot: Ashgate, 2001, pp. 13-39.

[9] T. Christensen, and P. Laegreid. New public management-Undermining political control. In: Christensen, T. Lægreid, P. New public management. The transformation of ideas and practice. Aldershot: Ashgate, 2001, pp. 93-120.

[10] W. Cukier, O. Ngwenyama, R. Bauer, and C. Midletton. A Critical Analyses of Media Discourse on Information Technology: preliminary results of a proposed method for critical discourse analyses. Info Systems Journal, 2008, 19, pp. 175-196. 
[11] M. A. Cunha, E. Przeybilovicz, J. F. M. Macaya, and F. Burgos. Smart Cities: Transformação Digital de Cidades. São Paulo: Programa Gestão Pública e Cidadania - PGPC, 2016. $161 \mathrm{p}$

[12] M. A. Cunha, T. R. Coelho, and M. Pozzebon. The Use of ICT in Public Decision-Making Participation. ECIS 2013 Proceedings.

[13] E. H. Diniz, A. F. Barbosa, A. R. B. Junqueira, and O. Prado. O governo eletrônico no Brasil: perspectiva histórica a partir de um modelo estruturado de análise. Revista de Administração Pública, 2009, 43(1), 23-48.

[14] N. Fairclough. Critical Discourse Analyses: The Critical Study of Language, 1995, Longman: London.

[15] K. Falconer Al Hindi, and K. Till, K. (Re) placing the new urbanism debates: toward an interdisciplinary research agenda, Urban Geography, 2001, 22(3), pp. 189-286.

[16] J. R. Gil-Garcia, L. F. Vivanco, and L. F. Luna-Reyes. Revisiting the problem of technological and social determinism: Reflections for digital government scholars. In: M. Janssen, F. Bannister, O. Glassey, H. J. Scholl, E. Tambouris, M. Wimmer, \& A. Macintosh (Eds.), Electronic government and electronic participation, 2014, pp. 254-263. Amsterdam, the Netherlands: IOS Press.

[17] J. R. Gil-Garcia, T. Pardo, and T. Nam. Smarter as the New Urban Agenda: A Comprehensive View of the 21st Century City, 2016. Springer.

[18] R. Goodspeed. Smart cities: moving beyond urban cybernetics to tackle wicked problems. Cambridge Journal of Regions, Economy and Society, 2015, 8(1), pp. 79-92.

[19] R. G. Hollands. Will the real smart city please stand up? Intelligent, progressive or entrepreneurial?. City, 2008, 12(3), pp. 303-320.

[20] A. Jonas, and A. While. Greening the entrepreneurial city? Looking for spaces of sustainability politics in the competitive city. In: R. Krueger and D. Gibbs (Eds) The Sustainable Development Paradox: Urban Political Economy in the United States and Europe, 2007, pp. 123159. New York: Guilford Press.

[21] D. F. Kettl. A revolução global: reforma da administração do setor público. In: Pereira, L. C. B \& Spink, P. (Edit.) Reforma do Estado e Administração Pública Gerencial, 2007, pp. 75- 121, Rio de Janeiro: FGV.

[22] R. Kitchin. The real-time city? Big data and smart urbanism. GeoJournal, 2013, 79(1), pp. 1-14.

[23] A. Kolsaker, L. Lee-Kelley. Citizens' attitudes towards e-government and e-governance: a UK study. International Journal of Public Sector Management, 2008, v. 21, n. 7, pp. 723-738.

[24] N. Komninos. Intelligent Cities: Innovation, Knowledge Systems and Digital Spaces, 2002, London: Routledge.

[25] G. Lawson. NetState - Creating electronic government, 1998, London: Demos.
[26] D. Maingueneau. Novas Tendências em Análise do Discurso, 1993, Campinas: UNICAMP.

[27] S. Marvin, A. Luque-Ayala, and C. McFarlane. Smart Urbanism: Utopian vision or false dawn? 2016, Routledge.

[28] C. McFarlane. Learning the City: Knowledge and Translocal Assemblage, 2011. Oxford: Wiley-Blackwell.

[29] A. Meijer, M. P. R. Bolívar. Governing the smart city: A review of literature on smart urban governance. International Review of Administration Science, 2015, pp. $1-17$

[30] T. Nam, and T. A. Pardo. Smart city as urban innovation: Focusing on management, policy, and context. Proceedings of the 5th International Conference on Theory and Practice of Electronic Governance-ICEGOV2011, Tallinn, Estonia, 2011, pp. 185-194. New York, USA: ACM Press.

[31] T. Nam, and T. A. Pardo. Conceptualizing smart city with dimensions of technology, people, and institutions. In Proceedings of the 12th Annual International Conference on Digital Government Research, College Park, MD, 2011, pp. 282-29. New York, USA: ACM Press.

[32] A. Ojo, C. E. Dzusupova. Exploring the nature of the smart cities research landscape. In J. R. Gil-Garcia, T. A. Pardo, \& T. Nam (Eds.). (2016). Smarter as the New Urban Agenda: A Comprehensive View of the 21st Century City (Vol. 11). Springer.

[33] A. Peci, O. P. Pieranti, S. Rodrigues. Governança e New Public Management: convergências e contradições no contexto brasileiro. Organizações \& Sociedade, 2008, 15(46), pp. 39-55.

[34] B. G. Peters, J. Pierre. Governance without government? Rethinking public administration. Journal of public administration research and theory, 1998, 8(2), pp. 223-243.

[35] Fraunholz, B., \& Unnithan, C. (2009). Does egovernance facilitate citizen empowerment in democracies? A critical discourse analysis. International Journal of Electronic Governance, 2(2-3), 131-155.

[36] M. P. A. Thompson. ICT, Power, and Developmental Discourse: A critical analyses. The Electronic Journal of Information Systems in Developing Countries, 2004, 20, pp. $1-26$.

[37] A. M. Townsend. Smart cities: big data, civic hackers, and the quest for a new utopia, 2013, Norton \& Company.

[38] A. Vanolo. Smartmentality: The smart city as disciplinary strategy. Urban Studies, 2013, pp. 1-16.

[39] J. C. Vaz. Administração pública e governança eletrônica: possibilidades e desafios para a tecnologia da informação. In: Cunha, M. A.; Frey, K.; Duarte, F. Governança local e as tecnologias de informação e comunicação. Curitiba: Editora Champagnat, 2009, pp. 195 - 206. 